\title{
Price transmission and supply response: the case of Indian small cardamom
}

\author{
A Indhushree* \& A Kuruvila \\ Department of Agricultural Economics, College of Horticulture, \\ Kerala Agricultural University, Vellanikkara-680 656, Thrissur, Kerala. \\ *E-mail: indhuashree@gmail.com
}

Received 12 October 2020; Revised 01 March 2021; Accepted 16 April 2021

\begin{abstract}
Market price volatility, the major challenge faced by the cardamom exporters greatly hinders the investment and destabilizes the earning of small holders. The present study attempted to analyse the price transmission between Indian and international markets and study the supply response of small cardamom to changes in price. The co-movement of prices of small cardamom exist between the Indian and international markets after trade liberalisation and the price transmission has been from the international market to the Indian market. The short-run disequilibrium has been found between the Indian and international prices of cardamom, which got corrected with varying speed of adjustment. The positive and significant elasticity of supply of small cardamom with respect to its own two year lagged price has been established. Crop specific price stabilization mechanism would help to overcome the wide fluctuations in prices of small cardamom.
\end{abstract}

Keywords: causality, demand, market integration, price, spice

\section{Introduction}

Indian small cardamom is well-known around the world for its quality and is exported to several countries. India, formerly the largest producer and exporter, is now the second largest producer and exporter in the world. The production and export were 12,940 tonnes and 2850 tonnes respectively in 2018-19 (Spices Board 2019).

The liberalization of trade policies has serious implications for price stability and trade competitiveness of Indian small cardamom. The factors such as transport and marketing costs, policy measures, local currency valuation, market structure, degree of processing of final consumption goods, the market share of production and consumption, and domestic policies influence the extent of price transmission from global to domestic markets. Frequent variations in the world prices have led to uncertainty in the decisions of the farmers on what crops to grow and the decision of countries on when to import the commodities, as their decisions highly rely on the past price levels. Price fluctuations of the plantation crops severely inhibit the investment and destabilize the earning of 
small holders (Anoopkumar 2013). The market price volatility is the major challenge faced by the cardamom exporters in the international market (George \& Cherian 2017). Among the plantation crops, cardamom shows the highest intra-year instability because of low storability and seasonality which makes inter-temporal arbitraging by keeping in stocks less possible (Anoopkumar 2013).

For perennial crops like small cardamom, studying the supply response is of great challenge owing to their extended period of output flows. Any adjustments in the future output actually depend on the present planting decisions of the farmers growing perennial crops. Any adjustment in the productive capacity of a particular plantation crop during a particular year is the net effect of the plantation decisions that modify both the total cultivated area and the age composition of the tree stocks in the past (Kalaitzandonakes \& Shonkwiler 1992).

The present study was undertaken with the objectives of analysing the price formation and transmission between Indian and international markets and to study the supply response of small cardamom to changes in price.

\section{Methodology \\ Data}

The monthly price of ungraded cardamom and graded cardamom (AGEB - Alleppey Green Extra Bold) in the domestic market and the international prices of Indian extra bold in the New York market were used for the analyses. The monthly price series from 1983 to 2018 was classified into pre-WTO period (1983 to 1994) and post-WTO period (1995 to 2018) and also classified into different decadal periods viz., period I (1983 to 1990), period II (1991 to 2000), period III (2001 to 2010) and period IV (2011 to 2018). In the case of graded cardamom, pre-WTO period and period I were not considered due to non-availability of data in these periods. The sources of data include Spices Market Weekly and Spice India published by Spices Board, Kochi; Agricultural Statistics and Statistics for Planning published by Directorate of Economics and Statistics, Thiruvananthapuram, Government of Kerala and the website of Spices Board.

For analysing the supply response of small cardamom, data were collected through primary survey in Idukki District of Kerala.

\section{Price transmission}

Prior to co-integration analysis, Augmented Dickey Fuller (ADF) test was carried out to establish the stationarity of the price series used in the study.

Johansen Maximum likelihood procedure (Johansen \& Juselius 1990) is considered to be the most applicable method to test for cointegration in a system of variables, as it allows for the cointegration between system of variables without enforcing bias on the estimates. It identifies co-integrating vectors between the non-stationary level variables in Vector Error Correction Model (VECM) context, which is a Vector Auto Regression model in the form of error correction. VECM treats individual variables as potentially endogenous and links the change in one variable to errors in the past equilibrium and also to past changes in all the variables.

As cointegration itself cannot indicate the direction of causation, Granger causality test was employed to identify the direction of price transmission between two price series (Granger 1980).

\section{Supply response of small cardamom production}

The supply response of small cardamom farmers in the Idukki District of Kerala was estimated by employing an alternative form of Nerlovian supply response model using Ordinary Least Squares regression (Sadoulet \& Janvry 1995). The specification of the supply 
response model for small cardamom is as follows:

$$
\begin{aligned}
\ln Q_{t}= & b_{0}+b_{1} \ln Q_{t-2}+b_{2} \ln P_{c t}+b_{3} \ln P_{c t-2}+b_{4} \ln \\
& P_{p_{t-2}}+b_{5} \ln R_{t-1}+b_{6} \ln T_{\max t-1}+b_{7} \ln T_{\min t-1} \\
& +b_{8} D U M_{t}
\end{aligned}
$$

where, $Q_{t}$ and $Q_{t-2}$ represent production of small cardamom at time $t$ and $t-2$, respectively. $\mathrm{P}_{\mathrm{ct}}$ and $\mathrm{P}_{\mathrm{ct}-2}$ are the price of small cardamom at time $t$ and $t-2$, respectively, while $P_{p t-2}$ is the price of competing crop (pepper) at time $t-2$. $R_{t-1}$ denotes rainfall at time $t-1$, while $T_{\max }$ $\mathrm{t}-1$ and $\mathrm{T}_{\min \mathrm{t}-1}$ indicate maximum and minimum temperatures at time $\mathrm{t}-1$. The dummy for trade liberalisation (0 - pre-liberalisation period and 1 - post-liberalisation period) is represented by DUM $_{\mathrm{t}}$

\section{Results and discussion}

\section{Price transmission}

The Augmented Dickey Fuller (ADF) test confirmed that the price series considered for the study was stationary (Table 1). As could be observed from Table 2, the Johansen cointegration analysis indicated the presence of cointegrating relationship between the price series of Indian ungraded cardamom in the domestic market and Indian Extra Bold in the New York market during the post-WTO period and periods I, II, III and IV. The cointegration existed between AGEB auction price in India and the international price of Indian Extra Bold during the post-WTO period, period III and period IV, as evident from Table 3.

The reduction in various trade barriers after liberalisation has led to better integration and transmission of prices between markets in the post-WTO period. The prices did not converge in absolute terms due to factors such as Non-Tariff Measures (NTMs), transport and transaction costs, extent of market power, scale economies, and extent of exchange rate pass through on output prices (IGIDR, 2011).

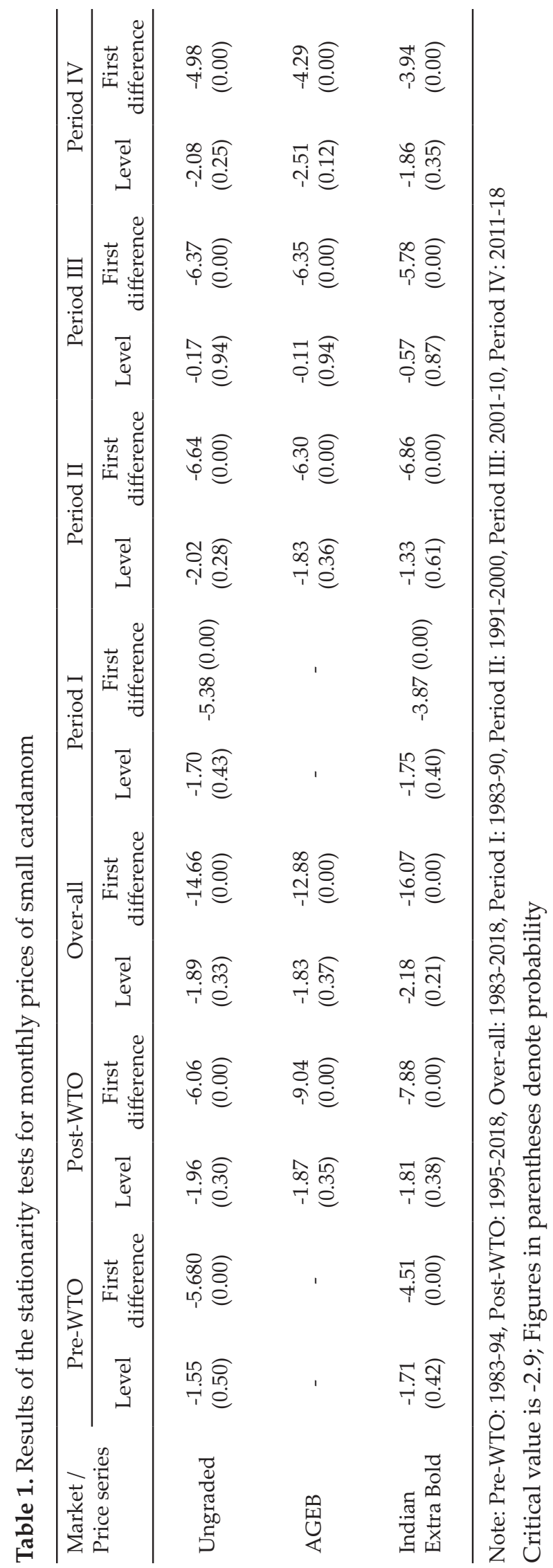




\section{Vector Error Correction Model (VECM):}

The results of VECM revealed that the information flow was more in the international market compared to the domestic market in all the periods considered, with the exception of period III for ungraded cardamom (Table 4) and periods III and IV for graded cardamom (AGEB) (Table 5). These indicate that the price adjustment occurs more quickly in the international market than in the domestic market. In the case of ungraded cardamom price, the coefficients of less than 0.5 indicated the slow pace of adjustment towards the equilibrium price while the speed of adjustment was high for graded cardamom.

As the higher value of the error correction term indicates higher rate of adjustment towards equilibrium, the speed of convergence for short-run price movements to become stable along the long-run equilibrium path was found to be increasing after the trade liberalisation. This could be attributed to the domestic market orientation of small cardamom since 1980's and higher tariff barriers in the pre-liberalisation period, which were considerably lowered in the post-liberalisation period, leading to better integration of markets.

\section{Granger causality test:}

The results of the Granger causality tests for different pairs of price series of small cardamom given in Table 6 revealed that the international market price Granger caused the price of both ungraded and graded (AGEB) cardamom in the domestic market in the periods considered.

India, a major producer and consumer of small cardamom in the world, could not influence the international market as, the major share of its production is oriented towards the domestic market due to the higher demand in the household, industrial and institutional segments (Narayanan 2004) and the traders are less motivated to export. Moreover, in the international market, Guatemalan cardamom dominates due to its cheaper price, while the price of small cardamom from India happened to be much higher. 
Table 3. Results of the pair-wise cointegration tests between Indian (graded) and international prices of small cardamom

\begin{tabular}{cccccccccccc}
\hline \multirow{2}{*}{ Null } & \multicolumn{2}{c}{ Post-WTO } & \multicolumn{2}{c}{ Overall } & \multicolumn{2}{c}{ Period II } & \multicolumn{2}{c}{ Period III } & \multicolumn{2}{c}{ Period IV } \\
\cline { 2 - 12 } & $\begin{array}{c}\text { Eigen } \\
\text { value }\end{array}$ & $\lambda$-trace & $\begin{array}{l}\text { Eigen } \\
\text { value }\end{array}$ & $\lambda$-trace & $\begin{array}{l}\text { Eigen } \\
\text { value }\end{array}$ & $\lambda$-trace & $\begin{array}{c}\text { Eigen } \\
\text { value }\end{array}$ & $\lambda$-trace & $\begin{array}{c}\text { Eigen } \\
\text { value }\end{array}$ & $\lambda$-trace \\
\hline $\mathrm{r}=0$ & 0.0949 & 31.39 & 0.0262 & 11.82 & 0.046 & 7.35 & 0.16 & 21.68 & 0.2482 & 28.48 \\
$\mathrm{r}<=1$ & 0.0131 & 3.66 & 0.0092 & 3.05 & 0.0151 & 1.79 & 0.0093 & 1.1029 & 0.0375 & 3.36 \\
\hline
\end{tabular}

Note: Pre-WTO: 1983-94, Post-WTO: 1995-2018, Over-all: 1983-2018, Period I: 1983-90, Period II: 1991-2000, Period III: 2001-10, Period IV: 2011-18

Critical value for $r=0$ is 15.49 and $r<=1$ is 3.84;

Markets and Prices considered: AGEB and New York Indian Extra Bold

Table 4. Estimates of Error Correction Model for Indian ungraded (UG) and Indian Extra Bold in New York (IEB)

\begin{tabular}{|c|c|c|c|c|c|c|c|}
\hline Period & Price series & ECM & $\mathrm{D}(\mathrm{UG}(-1))$ & $\mathrm{D}(\mathrm{UG}(-2))$ & $\mathrm{D}(\mathrm{IEB}(-1))$ & $\mathrm{D}(\mathrm{IEB}(-2))$ & $\mathrm{C}$ \\
\hline \multirow[t]{4}{*}{ Post-WTO } & $\mathrm{D}(\mathrm{UG})$ & -0.0882 & $0.2480^{* *}$ & -0.125 & 0.0919 & -0.0498 & 0.0039 \\
\hline & & $(0.0549)$ & $(0.0762)$ & $(0.0774)$ & $(0.104)$ & $(0.0985)$ & $(0.006)$ \\
\hline & D(IEB) & $0.1729^{* *}$ & $0.1242^{*}$ & $-0.1259^{*}$ & $0.2153^{* *}$ & -0.0446 & 0.0023 \\
\hline & & $(0.0365)$ & $(0.0507)$ & $(0.0515)$ & $(0.0692)$ & $(0.0656)$ & (0.0040 \\
\hline \multirow[t]{4}{*}{ Over-all } & D(UG) & -0.0016 & $0.2215^{* *}$ & $-0.1220^{*}$ & 0.0621 & -0.0244 & 0.0024 \\
\hline & & $(0.0167)$ & $(0.0541)$ & $(0.0556)$ & $(0.0804)$ & $(0.0777)$ & $(0.005)$ \\
\hline & D(IEB) & $0.0420^{* *}$ & $0.1593^{* *}$ & -0.0385 & $0.1559^{* *}$ & 0.0049 & 0.0019 \\
\hline & & $(0.011)$ & $(0.0355)$ & $(0.0364)$ & $(0.0527)$ & $(0.0509)$ & (0.003) \\
\hline \multirow[t]{4}{*}{ Period I } & D(UG) & 0.0017 & $0.2423^{*}$ & & -0.1164 & & $-3 \mathrm{E}-04$ \\
\hline & & $(0.0504)$ & $(0.1148)$ & & $(0.1987)$ & & $(0.012$ \\
\hline & D(IEB) & $0.1381^{* *}$ & -0.0047 & & -0.0029 & & 0.0086 \\
\hline & & $(0.0248)$ & $(0.0565)$ & & $(0.0977)$ & & $(0.006)$ \\
\hline \multirow[t]{4}{*}{ Period III } & D(UG) & $-0.2300^{*}$ & $0.3742^{* *}$ & & -0.167 & & 0.0045 \\
\hline & & $(0.1138)$ & $(0.1377)$ & & $(0.1636)$ & & $(0.01)$ \\
\hline & $\mathrm{D}(\mathrm{IEB})$ & $0.1893^{*}$ & $0.2220^{*}$ & & 0.0635 & & 0.0035 \\
\hline & & $(0.0917)$ & (0.1109) & & $(0.1318)$ & & $(0.008)$ \\
\hline \multirow[t]{4}{*}{ Period IV } & $\mathrm{D}(\mathrm{UG})$ & 0.0119 & -0.0523 & -0.0619 & 0.4205 & 0.1288 & $-4 \mathrm{E}-04$ \\
\hline & & $(0.1467)$ & $(0.1877)$ & $(0.1768)$ & $(0.2621)$ & $(0.2405)$ & (0.009) \\
\hline & D(IEB) & $0.2757^{* *}$ & -0.0497 & $-0.2225^{*}$ & $0.4980^{* *}$ & 0.2208 & -0.001 \\
\hline & & $(0.0907)$ & $(0.1161)$ & $(0.1094)$ & $(0.1621)$ & $(0.1489)$ & $(0.006)$ \\
\hline
\end{tabular}

Note: $1 .{ }^{*}$ denotes significant at ten per cent level, ${ }^{* *}$ denotes significant at five per cent level 2. Figures in parentheses denote Standard Error

3. C denotes constant term 


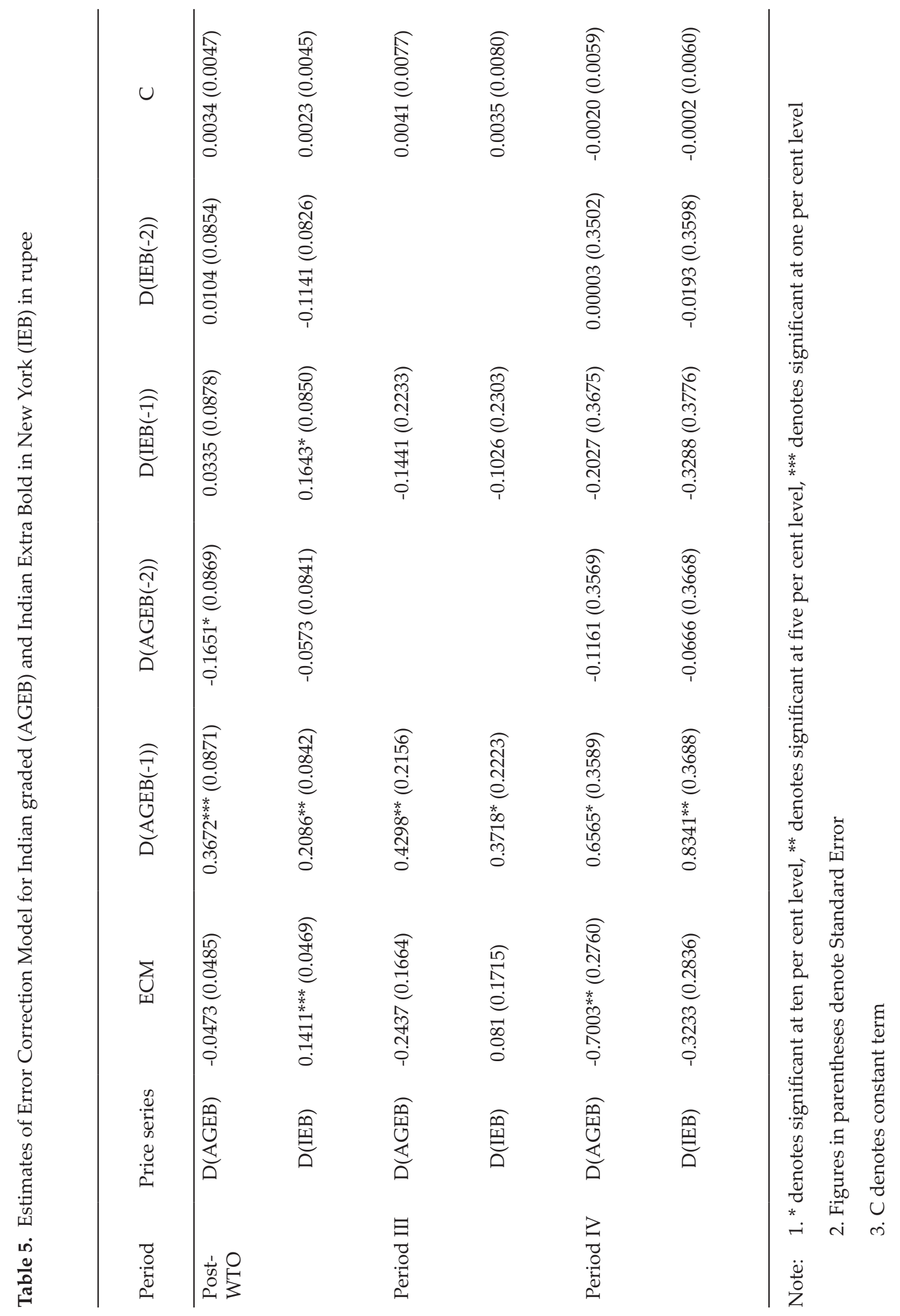


Table 6. Results of the Granger causality test for monthly prices of small cardamom in rupee

\begin{tabular}{|c|c|c|c|c|c|c|}
\hline \multirow[t]{2}{*}{ Null hypothesis } & \multicolumn{6}{|c|}{ F Stat values } \\
\hline & Post-WTO & Overall & Period I & Period II & Period III & Period IV \\
\hline $\begin{array}{l}\text { Ungraded India does not } \\
\text { Granger Cause Indian Extra } \\
\text { Bold New York }\end{array}$ & $20.22^{* * *}$ & $18.89^{* * *}$ & $17.55^{* * *}$ & - & $7.13^{* * *}$ & $3.28^{* *}$ \\
\hline $\begin{array}{l}\text { Indian Extra Bold New York } \\
\text { does not Granger Cause } \\
\text { Ungraded India }\end{array}$ & 1.91 & 0.04 & 1.16 & - & 2.03 & $2.64^{*}$ \\
\hline $\begin{array}{l}\text { AGEB does not Granger } \\
\text { Cause Indian Extra Bold New } \\
\text { York }\end{array}$ & $10.6^{* * *}$ & - & - & - & 2.05 & $2.71^{*}$ \\
\hline $\begin{array}{l}\text { Indian Extra Bold New York } \\
\text { does not Granger Cause } \\
\text { AGEB }\end{array}$ & 0.54 & - & - & - & 1.16 & 1.72 \\
\hline
\end{tabular}

\section{Supply response of small cardamom}

The result of the Nerlovian supply response model is given in Table 7. The coefficient of determination or $\mathrm{R}^{2}$ value of 97 per cent and probability of F-statistics indicated that the estimated supply response model was a good fit. The estimates showed that the lagged price was a significant factor in explaining the production of small cardamom in Idukki district. It was confirmed that the average annual rainfall in the cardamom growing tracts had relatively greater influence on the production of the crop.

As observed, the elasticity of small cardamom supply with respect to its own price lagged by two-years was positive and significant in both the short-run (0.39) and long-run (0.96).

Cardamom being cultivated under shaded condition and there was not much variation in the maximum and minimum temperature prevailing in the study area, the production was influenced by the rainfall rather than temperature. The higher and positively significant supply response of small cardamom to lagged domestic price and non-significance of liberalisation could be attributed to the higher inclination of the crop towards the domestic
Table 7. Estimates of the Nerlovian supply response model for small cardamom

\begin{tabular}{|c|c|c|}
\hline Sl. No. & Variable & Coefficient \\
\hline 1 & Intercept & 1.82 \\
\hline 2 & $\begin{array}{l}\text { Lagged production of } \\
\text { cardamom }\end{array}$ & $0.58^{* *}$ \\
\hline 3 & $\begin{array}{l}\text { Lagged price of } \\
\text { cardamom }\end{array}$ & $0.39^{* *}$ \\
\hline 4 & Lagged price of pepper & 0.09 \\
\hline 5 & Lagged rainfall & $0.33^{*}$ \\
\hline 6 & $\begin{array}{l}\text { Lagged maximum } \\
\text { temperature }\end{array}$ & -0.16 \\
\hline 7 & $\begin{array}{l}\text { Lagged minimum } \\
\text { temperature }\end{array}$ & 0.26 \\
\hline 8 & Dummy variable & 0.07 \\
\hline 9 & $\mathrm{R}^{2}$ & 0.96 \\
\hline 10 & Adjusted $\mathrm{R}^{2}$ & 0.95 \\
\hline 11 & F-statistic & $99.90^{* *}$ \\
\hline
\end{tabular}

market in the recent decades. Even though the demand in the international market declined after liberalisation owing to comparatively higher price of Indian cardamom and stiff competition from Guatemala, the demand in the domestic market has increased considerably. Thus, liberalisation has not influenced the total 
production and total supply of the commodity, which explains the non-significance of dummy variable i.e., liberalisation of trade. The results support the fact that farmers respond to increase in price by intensive application of inputs viz., fertilizers, pesticides and capital to increase the production. In the long-run, they responded to the increase in price by increasing the area under cardamom cultivation and the farmers were found to be more innovative in developing high yielding varieties and postharvest machineries (Bhadouria et al. 2012).

\section{Conclusion}

The study revealed the existence of comovement of small cardamom prices between the Indian and international markets after trade liberalisation and the price transmission has been from the international market to the Indian market. The short-run disequilibrium has been found between the Indian and international prices of cardamom, which got corrected with varying speed of adjustment. The positive and significant elasticity of supply of small cardamom with respect to its own two year lagged price has been established.

The competitiveness of Indian small cardamom in the international market need to be improved. The problem of price variations in the domestic market due to price variations in the international market can be overcome by crop specific price stabilization mechanisms in the country. This ensures stable income to the farmers and helps the farmers with the longterm investment decisions as the crop is highly price elastic in long-run.

\section{References}

Anoopkumar M 2013 Intra-year price instability of commercial crops in India: exploring the underlying dynamism. Int. J. Food Agric. Econ. 2(1): 145-156.
Bhadouria P S, Singh M L, Chandrasekhar V \& Kuruvila A 2012 Post-Harvest Handling and Marketing. NRPPD Report, CDS, Thiurvananthapuram, pp. 40-56.

George M \& Cherian E 2017 Emergent global marketing challenges for Kerala cardamom producers vis-à-vis the role of the Spices Board of India. Int. J. Community Dev. Manag. Stud. 1: 39-62.

Granger CW 1980 Testing for causality: a personal viewpoint. J. Econ. Dyn. Control 2: 329-352.

IGIDR [Indira Gandhi Institute of Development Research] 2011 Towards Improving Understanding of Agricultural Output, Agricultural Markets, and Price Formation in the Context of Food Security in India. Proposal submitted to Ministry of Agriculture, Government of India, 19p.

Johansen S \& Juselius K 1990 Maximum likelihood estimation and inference on cointegrationwith applications to the demand for money. Oxford Bull. Econ. Statist. 52(2): 169210.

Kalaitzandonakes N G \& Shonkwiler J S 1992 A state-space approach to perennial crop supply analysis. Am. J. Agric. Econ. 74(2): 343-352.

Narayanan S 2004 Commodity Prices and Their Effect on Investment Viability and Repayment: The Case of Indian Cardamom. Occasional Paper - 30, Department of Economic Analysis and Research, NABARD, Mumbai, 68 p.

Sadoulet E \& De Janvry A 1995 Quantitative Development Policy Analysis: Vol. 5. Johns Hopkins University Press, Baltimore and London, 438p.

Spices Board 2019 Spices Board statistics [on-line]. Available: http://indianspices.com. 